\title{
ANALISIS MODEL BISNIS BESI TUA DI INDONESIA (STUDI KASUS DI PT. PUTRA KEMUNING KARAWANG)
}

\author{
${ }^{1}$ Eman Sulaeman \\ ${ }^{2}$ Danang Kusnanto
}

\begin{abstract}
Program Studi S1 Manajemen, Fakultas Ekonomi, Universitas Singaperbangsa Karawang eman.sulaeman@staff.unsika.ac.id ${ }^{1}$, danang.kusnanto@fe.unsika.ac.id ${ }^{2}$
\end{abstract}

\begin{abstract}
ABSTRAK
Peluang bisnis besi tua saat ini sangat menarik karena selain cara kerjanya mudah, sirkulasi uangnya juga sangat besar. Pertumbuhan bisnis ini seiring dengan tumbuhnya industri di K abupaten Karawang dimana bisnis besi tua merupakan turunan dari industri yang ada, khususnya industri metal dan otomotif. Tujuan dari penelitian ini adalah untuk mengetahui bagaimana konsep model bisnis pada bisnis besi tua PT. Putra Kemuning dengan menggunakan bisnis model kanvas yang mencakup sembilan blok yaitu value propositions, channels, customer relationships, customer segments, revenue streams, key resources, key activities, key partners, cost structure. Sembilan blok bisnis model kanvas ini juga dijadikan sebagai unit analisis dalam penelitian ini. Metode penelitian yang digunakan adalah pendekatan kualitatif deskriptif dengan jenis penelitian studi kasus. Teknik analisis yang digunakan dalam penelitian ini adalah teknik analisis domain. Hasil penelitian dapat disimpulkan bahwa model bisnis menggunakan model bisnis kanvas telah mendukung proses operasi bisnis besi tua di PT. Putra Kemuning sesuai dengan harapan.
\end{abstract}

Kata kunci: Bisnis, Model Bisnis, Model Bisnis Kanvas, Bisnis Besi Tua

\begin{abstract}
Today's scrap metal business opportunity is very interesting because in addition to how it works easily, the circulation of money is also very large. The growth of this business is in line with the growth of industry in the Karawang Regency where the scrap metal business is a derivative of the existing industry, particularly the metal and automotive industries. The purpose of this study was to determine how the concept of the business model in the scrap metal business of PT. Putra Kemuning uses a canvas business model that includes nine blocks, namely value propositions, channels, customer relationships, customer segments, revenue streams, key resources, key activities, key partners, cost structures. The nine business blocks of the canvas model are also used as the unit of analysis in this study. The research method used is a descriptive qualitative approach to the type of case study research. The analysis technique used in this study is the domain analysis technique. The results of the study concluded that the business model using the canvas business model had supported the scrap metal business operations process at PT. Putra Kemuning in accordance with expectations.
\end{abstract}

Keywords: Business, Business Model, Canvas Business Model, Scrap Metal Business 


\section{PENDAHULUAN}

Pada masa lalu Karawang memiliki julukan lumbung padi nasional namun kini juga memiliki julukan tambahan yakni menjadi kota industri terbesar di Indonesia. Berdasarkan data BPS (Biro Pusat Statistik) Jawa Barat tahun 2018 bahwa Kabupaten Karawang menduduki rangking kedua setelah Indramayu yang menghasilkan padi. Predikat Karawang sebagai lumbung padi nasional, tentunya tidak menjadi hilang tetapi tetap dipertahankan oleh pemerintah Kabupaten Karawang. Berkaitan dengan julukan kota industri, dapat dilihat dari Karawang New Industry City (KNIC) bahwa kabupaten Karawang merupakan wilayah dengan kawasan industri terbesar di Indonesia (https://www.knic.co.id). Sesuai dengan julukannya sebagai kota industri, Karawang kini hadir dengan perusahaan-perusahaan yang berdiri di atas lahan penduduk dengan mayoritas pengguna Bahasa Sunda ini. Karawang menjadi kabupaten yang dipercaya oleh perusahaan asing untuk mendirikan usaha serta bisnisnya. Maka sangat wajar jika Karawang saat ini bahkan mampu mengalahkan Jakarta dari pendapatan penduduknya mengingat UMR (Upah Minim Regional) di Karawang menjadi yang terbesar di Indonesia (https://alphapay.id).

Di Karawang banyak berdiri berbagai macam perusahaan seperti perusahaan industri otomotif, metal, elektronik, tekstil dan lain-lain. Seiring dengan tumbuhnya industri tersebut muncul fenomena penjual besi tua, dimana bisnis besi tua yang merupakan turunan dari industri yang ada khususnya perusahaan dengan bahan baku utama metal seperti spare part dan otomotif.

Besi tua merupakan komoditas yang memiliki pasar tersendiri, permintaan rutin akan komoditi ini membuat banyak orang tergiur untuk menekuninya. Menurut data Kementerian Perindustrian, tahun 2015 produksi baja nasional 7 juta ton. Jika bahan baku dua kali lipat dari produksi, maka diprediksi kebutuhan bahan baku besi tua mencapai 14 juta ton. Sedangkan Berdasarkan data organisasi untuk pembangunan dan ekonomi (OECD) pada 2013, total kebutuhan baja di Indonesia mencapai 12,69 juta ton. Sedangkan 8,19 juta ton di antaranya berasal dari impor dengan nilai 14,9 miliar dolar AS. Saat ini, 70\% dari kebutuhan itu masih dipenuhi dengan impor. Artinya, 30\% kebutuhan besi tua dipenuhi dari dalam negeri atau angkanya 4 juta ton per tahun. Merujuk harga Steel Indonesia.com dimana besi tua Grade A sampai Grade C rata-rata Rp 4.500 per kg, maka estimasi kapitalisasi bisnis besi tua nasional mencapai Rp 18 triliun setahun atau sekitar Rp 1,5 triliun per bulan atau Rp 50 miliar per hari (http://www.bumn.go.id). 
Bisnis besi tua merupakan bisnis menarik dan menguntungkan, sekali transaksinya bisa sangat fantastis/milyaran. Walau yang dijual adalah besi tua, yang seringnya sudah karatan namun pengusaha besi tua yang sukses memiliki kantor yang biasanya lebih mewah dari kantor pengusaha lainnya. Awalnya para pengusaha besi scrap biasanya sekedar coba-coba menjual besi karena ikut teman, bisa sebagai penghubung (makelar) atau langsung sebagai penyuplai. Namun setelah mengetahui seluk beluk bisnis besi tua ini dan memiliki banyak jaringan pertemanan, barulah para pengusaha ini bersemangat untuk serius membangun bisnisnya.

Berdasarkan latar belakang yang telah dipaparkan di atas maka penelitian ini bermaksud untuk menganalisis model bisnis pada bisnis besi tua menggunakan model bisnis kanvas yang meliputi sembilan elemen penting dalam sebuah kegiatan bisnis. Osterwalder \& Pigneur (2010:14) mendefinisikan bahwa model bisnis merupakan sebuah model yang menggambarkan dasar pemikiran tentang bagaimana organisasi menciptakan, memberikan, dan menangkap nilai. Model bisnis dapat digambarkan dengan baik melalui sembilan blok bangunan dasar yang menunjukkan logika bagaimana perusahaan bermaksud menghasilkan uang, yaitu value propositions, channels, customer relationships, customer segments, revenue streams, key resources, key activities, key partners, cost structure.

\section{METODE PENELITIAN}

\section{Jenis Penelitian}

Jenis penelitian yang digunakan dalam penelitian ini adalah deskrptif dengan metode kualitatif. Creswell (2012) dalam Sugiono (2015) mengungkapkan bahwa penelitian kualitatif berarti proses mengeksplorasi dan memahami makna individu atau kelompok, menggambarkan masalah sosial atau kemanusiaan. Proses penelitian melibatkan pertanyaan dan prosedur yang masih bersufat sementara, mengumpulkan data partisipan, menganalisis data secara induktif, membangun data yang parsial ke dalam tema dan membuat interpretasi makna suatu data. Menurut Sekaran (2007:158) yang dikutip oleh David Adhitya \& Marheni Eka (2016) bahwa studi deskriptif dilakukan untuk mengetahui dan menjadi mampu untuk menjelaskan karakteristik variabel yang diteliti dalam suatu situasi.

Penelitian ini menggunakan teknik analisis data yang berupa pengolahan data yang diperoleh peneliti selama di lapangan serta mengolah hasil wawancara dan dokumentasi. Teknik yang digunakan untuk menganalisa data menurut Spradley dalam Sugiyono (2015:415) ada empat 
yaitu analisis domain, taksonomi, komponensial dan tema kultural. Dalam penelitian ini analisis yang digunakan yaitu analisis domain, dimana analisis ini dilakukan untuk memperoleh gambaran yang umum dan menyeluruh dari obyek/penelitian atau situasi sosial.

Pada penelitian kualitatif tidak mengenal istilah populasi melainkan unit sosial yang terdiri atas tiga elemen, yaitu tempat (place), pelaku (actors), dan aktivitas (activity) yang berinteraksi secara sinergis. Situasi sosial tersebut, dapat dinyatakan sebagai objek penelitian yang ingin dipahami secara lebih mendalam "apa yang terjadi” di dalamnya. Pada penelitian ini PT. Putra Kemuning menjadi unit sosial yang akan diteliti serta seluruh komponen yang berhubungan langsung dengan kegiatan bisnis PT. Putra Kemuning yang disebut sebagai unit analisis.

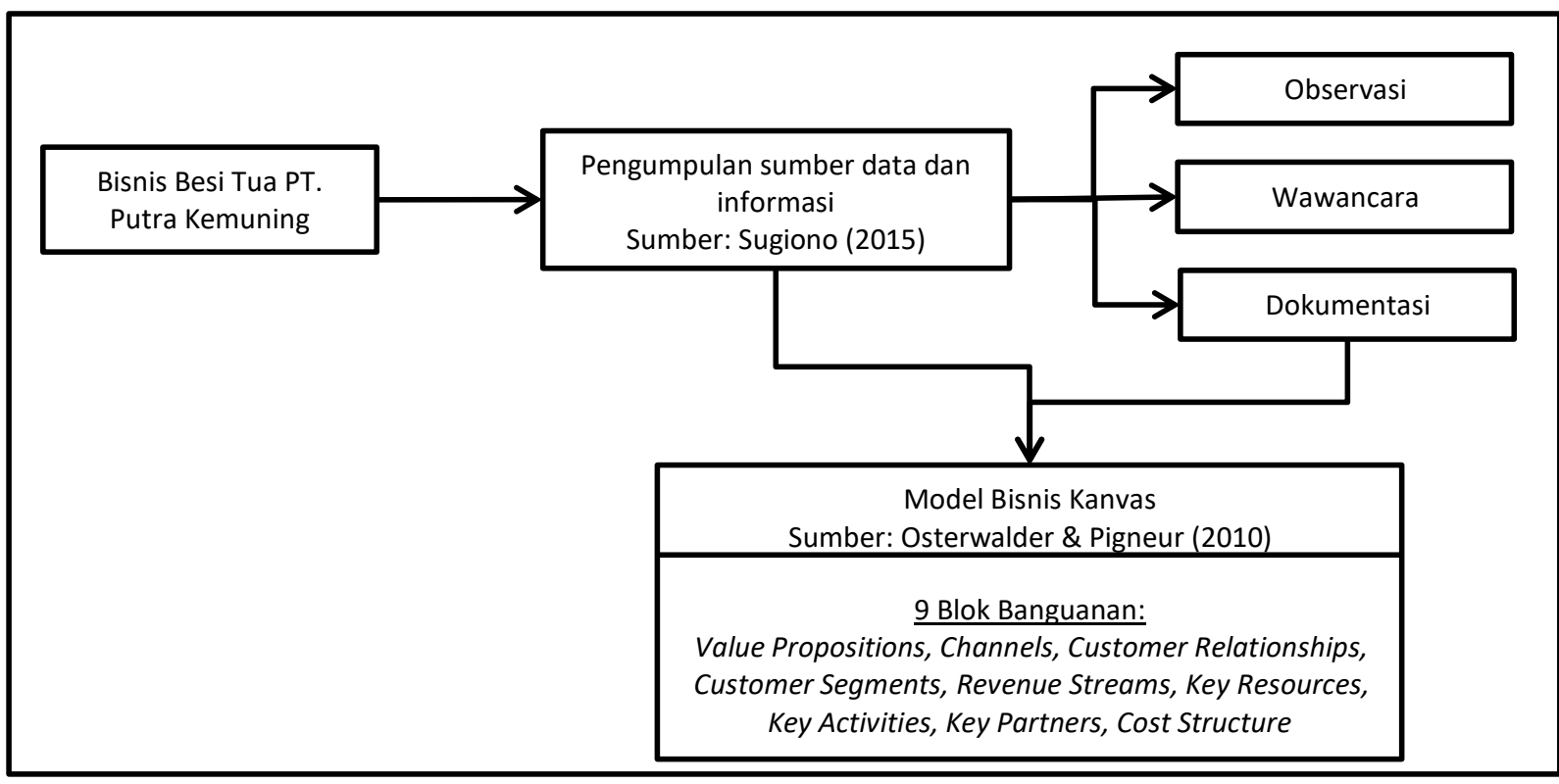

Gambar 1. Kerangka Pemikiran

\section{Waktu dan Tempat Penelitian}

Waktu pelaksanaan penelitian ini dalam waktu selama bulan September - November 2019. Adapun tempat penelitian ini dilaksanakan di PT. Putra Kemuning Kecamatan Telukjambe Barat, Kabupaten Karawang.

\section{Target/Subjek Penelitian}

Subjek yang diteliti oleh peneliti adalah pengusaha besi tua di PT. Putra Kemuning karena untuk mengetahui fokus penelitian mengenai model bisnis kanvas PT. Putra Kemuning.

\section{Prosedur Penelitian}


Prosedur dalam penelitian ini disusun agar pelaksanaanya terarah dan sistematis. Menurut Moleong, ada empat tahapan dalam prosedur pelaksanaan penelitian yaitu sebagai berikut :

1) Tahap pra lapangan

Peneliti mengadakan survei pendahuluan yakni mencari subjek sebagai narasumber. Selama proses survei ini peneliti melakukan tindak lanjut lapangan terhadap latar penelitian, mencari data, dan informasi tentang PT. Putra Kemuning. Peneliti juga menempuh upaya konfirmasi ilmiah melalui penelusuran literatur buku dan referensi pendukung penelitian. Pada tahap ini peneliti melakukan penyusunan rancangan penelitian berupa garis besar metode penelitian yang digunakan dalam melakukan penelitian. Tahap pra lapangan dilakukan peneliti pada awal bulan September 2019.

2) Tahap pekerjaan lapangan

Dalam hal ini peneliti memasuki dan memahami latar penelitian dalam rangka pengumpulan data. Tahap ini dilaksanakan pada pertengahan September sampai akhir September 2019.

3) Tahap analisis data

Tahapan yang ketiga dalam penelitian ini adalah analisis data. Penelitian dalam tahapan ini melakukan serangkaian proses analisis data kualitatif sampai pada interpretasi data-data yang telah diperoleh sebelumnya. Selain itu peneliti juga menempuh proses pengecekan kebenaran data atau informasi yang diperoleh peneliti diperbandingkan dengan teori kepustakaan. Tahap analisis data dilakukan pada bulan Oktober 2019.

4) Tahap evaluasi dan pelaporan

Pada tahap ini peneliti berusaha melakukan konsultasi dan pembimbingan dengan beberapa pihak selama bulan November 2019.

\section{Data, Instrumen, dan Teknik Pengumpulan Data}

Sumber pengumpulan data yang digunakan peneliti adalah data primer yang berupa hasil wawancara dan data sekunder yang bersumber dari buku, jurnal, literature, dan dokumen lainnya yang berhubungan dengan masalah penelitian.

Pengumpulan data sebuah penelitian yang dilakukan dengan berbagai metode-metode penelitian seperti observasi, wawancara, studi pustaka, dan dokumentasi, memerlukan alat bantu sebagai instrumen. Instrumen yang dimaksud yaitu kamera, handphone untuk recorder, pensil, pulpen, dan buku. Instrumen yang digunakan melalui observasi dan wawancara yang dilakukan peneliti fokus kajian yang diteliti meliputi sembilan blok model bisnis kanvas. Sedangkan melalui 
wawancara, peneliti mempersiapkan beberapa pertanyaan untuk dijadikan bahan data atau sumber yang relevan dalam penelitian tersebut.

Adapun proses pengumpulan data terhadap suatu penelitian yang penulis lakukan, maka harus memiliki cara atau teknik untuk mendapatkan data atau informasi yang baik dan terstruktur serta akurat dari setiap apa yang diteliti, sehingga kebenaran informasi data yang diperoleh dapat dipertanggungjawabkan. Tekniknya meliputi pertama, observasi mengungkapkan gambaran sistematis mengenai peristiwa yang dihasilkan dan peralatan yang digunakan untuk memperoleh data yang tepat, akurat, dan dapat dieprtanggungjawabkan. Kedua, wawancara merupakan suatu metode pengumpulan data yang digambarkan sebagai sebuah interaksi yang melibatkan antara pewawancara dengan yang diwawancarai dengan maksud mendapatkan informasi yang sah dan dapat dipercaya. Dan ketiga, studi pustaka dan dokumentasi yang biasanya digunakan untuk memperoleh informasi yang berbentuk berbagai catatan berupa buku, leaflet, pamplet surat kabar, katalog, video, foto, dan catatan lainnya yang berkaitan dengan karya yang dikaji, sehingga diperoleh data-data yang dapat dipertanggungjawabkan kebenarannya. Bahkan tidak menutup kemungkinan, penulis juga mencari data dokumentasi melalui internet yang tetap memperhatikan kebenaran informasinya.

\section{Teknik Analisis Data}

Setelah data-data yang penulis perlukan terkumpul, maka langkah selanjutnya adalah menganalisis data. Analisis data yang penulis gunakan pada penelitian ini menggunakan analisis kualitatif mencakup hasil wawancara, reduksi data, analisis, interpretasi data, dan triangulasi. Dari hasil analisis data yang kemudian dapat ditarik kesimpulan.

\section{HASIL PENELITIAN DAN PEMBAHASAN}

\section{Hasil Penelitian}

Peneliti melakukan pengumpulan data dengan cara observasi, wawancara dan dokumentasi untuk membuat business model existing pada bisnis bisnis besi tua di PT. Putra Kemuning dengan bantuan model bisnis kanvas yang terdiri dari 9 blok bangunan berikut ini:

\section{Value propositions (Proposisi Nilai)}

PT. Putra Kemuning sebagai salah satu perusahaan terbesar di Kabupaten Karawang yang bergerak pada bisnis limbah menawarkan proposisi nilai berupa harga beli besi tua dan jual besi tua yang kompetitif di pasar. Hal ini didasari oleh karena semakin banyaknya kompetitor yang bergerak dibidang bisnis besi tua ini sehingga competitive advantage merupakan jawabannya. Berikutnya adalah Legalitas dan dokumen yang lengkap seperti izin impor scrap, izin B3, dan membuka L/C, memang terlihat berbirokrasi panjang, namun 
selanjutnya dengan kelengkapan tersebut akan pelaku bisnis akan mendapat kemudahan dan banyak keuntungan.

\section{Channels (Saluran)}

Dalam penelitian ini, channels adalah sebuah cara untuk mendistribusikan produk hingga sampai kepada customer. Pada dasarnya PT. Putra Kemuning merupakan perusahaan perantara yang menyalurkan besi tua dari mitra pemasok kepada perusahaan peleburan, sehingga saluran distribusi yang dipilih adalah saluran distribusi langsung. Saluran distribusi langsung adalah produk disalurkan langsung kepada konsumen akhir tanpa melalui perantara.

3. Customer relationships (Hubungan Pelanggan)

Kaitan dengan cara menjaga relasi customer untuk tetap terjaganya hubungan baik dan loyalitas maka PT. Putra Kemuning melakukan silaturahmi secara berkala baik secara fomal maupun informal bersama cutomer dan menjaga komitmen bisnis seperti pengiriman dan pembayaran tepat waktu.

4. Customer segments (Segmen Pelanggan)

PT. Putra Kemuning merupakan perusahaan perantara yang menyalurkan besi tua dari mitra pemasok kepada perusahaan peleburan, sehingga yang menjadi segmen pelanggan dari PT. Putra Kemuning adalah pabrik peleburan biji besi yang berlokasi di Jakarta.

5. Revenue stream (Aliran Pendapatan)

Yang menjadi sumber arus pendapatan bisnis besi tua yang dijalankan oleh PT. Putra Kemuning adalah penjualan produk besi tua itu sendiri, yaitu penjualan kepada pabrik peleburan besi.

6. Key resources (Sumber Daya Utama)

Sumber daya utama yang dimiliki PT. Putra Kemuning untuk menjalankan kegiatan bisnisnya sehari-hari meliputi sarana prasarana seperti gudang sebagai lokasi penyimpanan sementara besi tua dan kendaraan sebagai sarana logistik. Sumber daya utama yang tidak kalah penting adalah sumber daya manusia atau karyawan perusahaan serta sejumlah modal yang menopang berjalannya aktivitas sebuah bisnis.

7. Key activities (Aktivitas Kunci)

PT. Putra Kemuning memiliki tiga macam aktivitas kunci dalam bisnisnya, pertama pengumpulan besi tua dari beberapa perusahaan manufaktur, pengepul dan masyarakat umum sebagai pemasok, kedua adalah aktivitas penyortiran besi tua sesuai dengan kelasnya karena kelas besi tua akan mempengaruhi harga, serta ketiga adalah kegiatan pemasaran besi tua kepada pabrik peleburan yang berlokasi di Jakarta.

8. Key partners (Mitra Utama)

Mitra utama perusahaan dalam menjalankan kegiatan bisnis sehari-harinya saat ini ada beberapa yaitu beberapa perusahaan manufaktur yang menjadi pemasok besi tua, pengepul besi tua dan asosiasi pengusaha besi tua.

9. Cost structure (Struktur Biaya)

Biaya-biaya yang harus dikeluarkan oleh PT. Putra Kemuning dalam kegiatannya seharihari meliputi biaya pembelian besi tua, biaya operasional, biaya distribusi/angkutan, gaji karyawan, biaya administrasi dan pembayaran pajak sebagai kewajiban. 
Dari sembilan blok bangunan yang sudah ditentukan itemnya maka langkah selanjutnya peneliti melakukan pemetaan konsep model bisnis besi tua pada PT. Putra Kemuning kedalam model bisnis kanvas sebagai berikut:

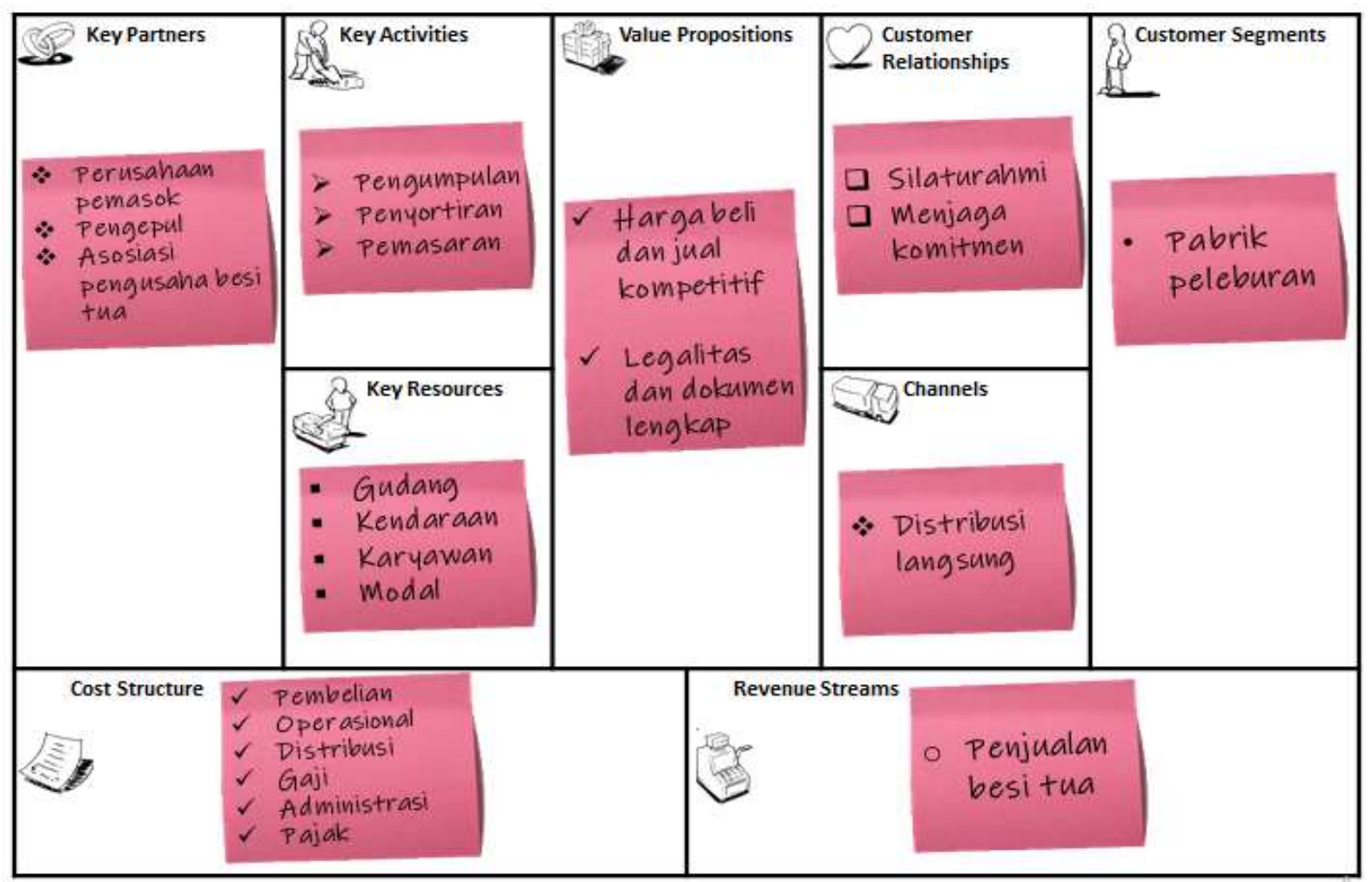

Gambar 2. Bisnis Model Kanvas PT. Putra Kemuning

\section{Pembahasan}

Berdasarkan hasil observasi dan wawancara dengan narasumber terdapat beberapa hal yang menjadi temuan. Dikaitkan dengan konsep bisnis model kanvas dimana menurut studi literatur pada blok cost structure menggambarkan semua biaya yang dikeluarkan untuk mengoperasikan model bisnis ditemukan bahwa perusahaan seringkali dihadapkan pada masalah harga yang sangat sulit di prediksi, akibatnya terjadi kerugian besar karena salah prediksi. Dulu siklus harga barang bekas itu sangat mudah di prediksi, harga turun dan naik sudah bisa di perkirakan, setelah harga turun beberapa minggu kemudian akan naik kembali bahkan bisa melampaui harga semula sehingga dimana masanya harga turun biasanya lapaklapak akan menimbun barang bekas mereka hingga harga naik kembali baru mereka jual, dengan begitu mereka terhindar dari kerugian bahkan bisa meraup banyak untung ketika harga naik melampaui harga semula. Apa yg terjadi saat ini harga sangat sulit di prediksi, setelah turun harga bukannya membaik malah semakin turun, setelah lama di tunggu belum juga naik atau kembali ke harga semula, akhirnya barang menumpuk tidak dijual, modal tidak berputar akhirnya mau tidak mau harus dijual di bawah harga beli alias rugi. 
Atas permasalahan tersebut penulis merekomendasikan kepada perusahaan yang pertama bahwa perusahaaan harus merubah pola fikir dimana setelah harga turun akan naik kembali beberapa minggu kemudian, itu pola fikir lama yang sudah tidak sesuai lagi dengan perkembangan zaman. Perusahaan sebaiknya mulai mencari informasi lebih luas, tidak hanya terpaku pada informasi yg datang dari pabrik peleburan atau pabrik daur ulang, ikuti pula informasi perkembangan program pemerintah dalam hal kebijakan ekonomi, pembangunan, ekspor impor, harga minyak dunia,dan perdamaian dunia. Selanjutnya lakukan rotasi cepat, jangan takut rugi karna harga turun kalau sudah waktunya menjual jual saja, intinya jalankan sistem perputaran cepat, kalaupun kena rugi cuma sekali itupun bisa tergantikan pada saat harga naik nanti,yg penting modal terus berputar agar bisnis tetap bisa berjalan.

Mengenai Key Resources pada bisnis besi tua sudah menjadi permasalahan umum perihal masalah kebersihan dan keselamatan, tantangannya adalah lingkungan yang kotor, berdebu dan cenderung kumuh sehingga mengancam kesehatan karyawan dalam jangka pendek maupun jangka panjang. Besi tua dan scrap tidak sedikit yang tajam dan berkarat juga menjadi ancaman bagi keselamatan kerja karyawan. Sebaiknya PT. PUTRA KEMUNING lebih memperhatikan masalah Keselamatan dan Kesehatan Kerja (K3) ini dengan menjaga kondisi lingkungan kerja yang lebih sehat dan menyediakan Alat Pelindung Diri (APD) seperti sepatu safety, sarung tangan, masker dan lain-lain yang standar dan dapat memenuhi kebutuhan akan keselaman dan kesehatan kerja bagi para karyawannya. Perlindungan kepada para karyawan juga bisa dilakukan melalui program asuransi, dalam bentuk asuransi kesehatan maupun kecelakaan kerja. Diharapkan ketika kondisi lingkungan sehat dan nyaman dan perasaan tenang dirasakan karyawan maka produktivitas kerja para karyawan juga dapat meningkat.

\section{KESIMPULAN DAN IMPLIKASI}

Berdasarkan hasil dan pembahasan penelitian didapatkan sebuah gambaran secara jelas dan rinci mengenai sebuah gambaran model bisnis existing pada PT. Putra Kemuning yang dipetakan dalam sembilan blok model bisnis kanvas yaitu pada blok Proposisi Nilai menawarkan berupa harga beli besi tua dan jual besi tua yang kompetitif di pasar, legalitas dan dokumen yang lengkap. Pada blok Saluran pilihan distribusi yang dipilih adalah saluran distribusi langsung. Dalam menjalin Hubungan Pelanggan PT. Putra Kemuning aktif melakukan silaturahmi dan selalu menjaga komitmen bisnis. Segmen pelanggan yang ada adalah pabrik peleburan biji besi yang berlokasi di Jakarta. Aliran Pendapatan berasal dari penjualan produk besi tua itu sendiri, yaitu penjualan kepada pabrik peleburan besi. Sumber daya utama untuk menjalankan kegiatan bisnisnya sehari-hari meliputi sarana prasarana seperti gudang, kendaraan, sumber daya manusia serta sejumlah modal yang menopang berjalannya aktivitas sebuah bisnis. PT. Putra Kemuning memiliki tiga macam aktivitas kunci dalam bisnisnya, pertama pengumpulan, penyortiran dan pemasaran besi tua. Mitra utama perusahaan dalam menjalankan kegiatan bisnis sehari-harinya saat ini ada beberapa yaitu beberapa perusahaan manufaktur yang menjadi pemasok besi tua, pengepul besi tua dan asosiasi 
pengusaha besi tua. Terakhir struktur biaya dikeluarkan meliputi biaya pembelian besi tua, biaya operasional, biaya distribusi/angkutan, gaji karyawan, biaya administrasi dan pembayaran pajak.

Berdasarkan hasil observasi dan wawancara dikaitkan dengan konsep bisnis model kanvas ditemukan beberapa persoalan yaitu pada blok cost structure dimana perusahaan seringkali dihadapkan pada masalah harga yang sangat sulit di prediksi, akibatnya terjadi kerugian besar karena salah prediksi. Mengenai Key Resources pada bisnis besi tua sudah menjadi permasalahan umum perihal masalah kebersihan dan keselamatan, tantangannya adalah lingkungan yang kotor, berdebu dan cenderung kumuh sehingga mengancam kesehatan karyawan dalam jangka pendek maupun jangka panjang. Besi tua dan scrap tidak sedikit yang tajam dan berkarat juga menjadi ancaman bagi keselamatan kerja karyawan.

Dan atas simpulan yang telah diuraikan, peneliti memberikan beberapa saran terhadap beberapa permasalahan yang ditemukan, pada permasalahan blok cost structure perusahaan sebaiknya mulai mencari informasi lebih luas, selain dari pabrik peleburan perlu mengikuti pula informasi perkembangan program pemerintah dalam hal kebijakan ekonomi, pembangunan, ekspor impor, harga minyak dunia,dan perdamaian dunia. Selanjutnya melakukan rotasi cepat, jangan takut rugi karna harga turun kalau sudah waktunya menjual jual saja, intinya jalankan sistem perputaran cepat, kalaupun kena rugi cuma sekali itupun bisa tergantikan pada saat harga naik nanti,yg penting modal terus berputar agar bisnis tetap bisa berjalan. Kemudian saran pada blok Key Resources sebaiknya PT. Putra Kemuning lebih memperhatikan masalah Keselamatan dan Kesehatan Kerja dengan menjaga kondisi lingkungan kerja yang lebih sehat dan menyediakan Alat Pelindung Diri serta memberikan perlindungan kepada karyawan melalui program asuransi, dalam bentuk asuransi kesehatan maupun kecelakaan kerja. Diharapkan ketika kondisi lingkungan sehat dan nyaman dan perasaan tenang dirasakan karyawan maka produktivitas kerja para karyawan juga dapat meningkat.

\section{DAFTAR PUSTAKA}

Adhitya, D., \& Eka, M. (2016). Analisis Model Bisnis Pada Bisnis Sepatu Guten.Inc Menggunakan Model Bisnis Kanvas. Bandung: Jurnal Sosioteknologi Vol 15, No 3 (2016). Diakses pada 12 Oktober 2019 dari: http://journals.itb.ac.id/index.php/sostek/article/view/2414.

BPS Jabar (2018). Luas Panen dan Produksi Padi di Jawa Barat2 018, No. 60/11/32/Th. XX, 1. Diakses pada 10 Oktober 2019 dari: Https://jabar.bps.go.id/pressrelease/2018/11/01/682/luas-panen-dan-produksi-padi-dijawa-barat-2018.html

Carol M. Kopp (2019) Business Model https://www.investopedia.com/terms/b/businessmodel.asp diakses 14 September 2019 
Fakhri Zahir (2019). UMP, UMK, dan UMR Setiap Daerah di Tahun 2019. Diakses pada 10 Oktober 2019. Https://alphapay.id/ump-umk-umr-2019/

Jangan Anggap Remeh Bisnis Besi Tua. (2017). Diakses pada 10 Oktober 2019 dari:

Http://www.bumn.go.id/istaka/berita/0-Jangan-Anggap-Remeh-Bisnis-Besi-Tua

KBBI (2016). KBBI Daring. Jakarta: kbbi.kemdikbud . Diakses pada 11 Oktober 2019.

Https://kbbi.kemdikbud.go.id/entri/bisnis

Kota Industri Karawang merupakan yang Terbesar di Indonesia. (2019). Diakses pada 10

Oktober 2019 dari: Https://www.knic.co.id/ja/kota-industri-karawang-merupakan-yangterbesar-di-indonesia

Mengenal Besi Scrap Atau Besi Tua. (2019). Diakses pada 10 Oktober 2019.

https://histeel.co.id/news/32/mengenal-besi-scrap-atau-besi-tua

Mohammad, R.K., \& Hendratmi, A. (2015). Business Model Canvas Pada BMT Kanindo

Syariah Malang. Malang: Repository Unair. Diakses pada 12 Oktober 2019 dari:

http://repository.unair.ac.id/6907/

Nielsen, C., \& Lund, M., Eds. (2013). The Basics of Business Models. London: bookboon.

Diakses pada 11 Oktober 2019 dari: https://bookboon.com

Osterwalder \& Pigneur (2010). Business Model Generation. Hoboken, NJ: Wiley. Diakses pada 11 Oktober 2019 dari: Https://b-ok.cc/

Sugiono (2015). Metode Penelitian Manajemen. Bandung: Alfabeta 